\title{
China's 13th Five-Year Plan: A Draft Proposal
}

\author{
KJELD ERIK BRØDSGAARD
}

Despite over 35 years of reform, some things in China never change. Thus, regular Five-Year Plans are still being formulated to serve as guidelines for the leadership's economic development policy priorities. The first Five-Year Plan was released in 1953 and only during the Great Leap Forward (1958-60) was the planning process suspended. Since the 1950s, overall planning has been conducted under the direction of the Chinese Communist Party (CCP). The CCP defines the goals to be reached and the guidelines to be followed. These are outlined in a draft document, which is formally confirmed at a subsequent spring meeting of the National People's Congress (NPC). In the period between the passing of the draft at a meeting of the CCP's central committee and the meeting of the NPC, there may be adjustments and concretizations, but these will not result in major changes.

The first Five-Year Plan emphasized heavy-industrial development, and this trend continued through subsequent plans. By way of high investment rates and the price-scissors, which channeled resources from agriculture to industry, Chinese planners built an oversized heavyindustrial complex (Brødsgaard and Rutten 2015). Even after the decision was made to begin a new phase of reform and open door policies, the old pattern of pouring resources into heavy industry continued to dominate and investment kept increasing to reach record high levels of almost 50 per cent of GDP.

\section{New Development Model}

The 12th Five-Year plan, covering the period 2011-2015, was the first to seriously attempt a change of the economic development model from lopsided focus on heavy industry to a more balanced and coordinated development of the main sectors of the economy (Brødsgaard 2011). Development priorities shifted to a strategy characterized by green development and a higher focus on social welfare or 'the people's wellbeing'. Key concepts and formulations were the 'scientific development concept' and 'taking the people as the foundation'. It was the final 
Five-Year Plan of the era of Hu Jintao and Wen Jiabao, laying down a course which they hoped the new leadership under Xi Jinping and Li Keqiang would follow.

Proposals for the 13th Five-Year Plan were discussed and reviewed during the Fifth Plenary Session of the 18th CCP Central Committee, which convened in Beijing from 26-29 October 2015 (Xinhua 2015c). A final plan will be ratified by the annual session of the National People's Congress in March 2016. However, barring major political change, the policies objectives and priorities of the plan will not be changed.

The new Five-Year Plan comes at a crucial time, when China's economic growth is slowing down. In 2014 the economy grew 7.4 per cent (National Bureau of Statistics 2015), compared to an average annual economic growth rate of 9.9 per cent during the previous 35 years. This year economic growth has slowed further and in the third quarter of 2015, the growth rate dropped to 6.9 per cent (Yin 2015), the first time the quarterly growth rate has dropped below 7 per cent since the global financial crisis in 2009. However, since the economy expanded at an annual rate of 8 per cent between 2011 and 2014, the target of an average annual growth of 7 per cent will without doubt be fulfilled.

Chinese leaders have characterized the shift from previous high-growth to a medium-to-high speed growth as China's 'new normal'. This is a new buzzword in current economic discussion in China, and it is also provides the key to understanding the thinking behind the new Five-Year Plan. The 'new normal' scenario does not envisage a planned fixed economic growth rate. However, the plan stipulates that the goal is to double Chinese GDP between 2010 and 2020. Based on current economic circumstances this will involve an annual growth rate of at least 6.5 per cent for the rest of the decade. In the past Chinese leaders continuously strove to surpass planned growth targets. However, this time around all indications are that the focus will instead be shifted to balanced development and the quality of economic growth, with industrial upgrading, innovation and green development at the centre. This also involves developing the service sector, promoting agricultural modernization, alleviating poverty, and building eco-friendly production and consumption modes.

\section{Environment}

China has replaced the USA as the manufacturing hub of the world. A quick look at the latest available statistical communiqué of Chinas economic indicators shows the enormous manufacturing capabilities of the 
country (National Bureau of Statistics 2015). Last year China produced 2.1 trillion tons of coal, 822 million tons of steel, 24 billion tons of cement, 141 million TV sets, 13 million passenger cars, 87 million household refrigerators, 1.6 billion mobile telephones and 350 million micro-computers. This position as the factory of the world has come with huge environmental costs. During the winter season many of the big cities in North and Northeast China regularly experience air pollution that exceeds hazard levels by 10 to 15 times. The country now has by far surpassed the USA as the top CO2 emitter in the world (Wübbeke and Conrad 2015).

The Chinese government has realized that pollution now is so serious that it poses critical health risks. At the annual session of the National People's Congress in March 2014, Prime Minister Li Keqiang declared war on pollution and since then a number of measures have been introduced with the ambition of creating a so-called ecological civilization. In May 2015 the State Council issued a national strategy to promote eco-civilization, listing 10 major goals including reduction of pollutant emissions. Thus by 2020 carbon dioxide emission will be reduced by 40 to 45 per cent from 2005 levels (Yin 2015).

Local state environmental bureaus have until recently been understaffed and functioning under the jurisdiction of local governments. They will now be better staffed and strengthened in terms of rank in order to withstand pressure from local officials who focus their attention solely on economic development. Perhaps even more importantly, government officials will in the future be held responsible for pollution beyond their terms of office. Already in the 12th Five-Year Plan environmental concern was mentioned as one of the key indicators when evaluating the performance of local officials.

Section V of the draft Five-Year Plan is devoted to green development, showing the focus on improving the 'ecological environment'. It stipulates that the government 'will support green and clean production, promote green transformation of traditional manufacturing, advance green and low-carbon industrial system of circular development, and encourage the upgrading and renovation of techniques, technology, and equipment of enterprises' (Xinhua 2015c: 14). In order to co- finance green development a Green Development Fund will be established.

\section{Innovation and quality}

The draft Five-Year Plan stresses not only that industrial production should be based on environmental concerns, it should also be innova- 
tion-driven and efficient in terms of the allocation of production factors like labour, capital, land, technology and management (Section III). In an attempt to foster new engines of development, it is the intention to promote the leading role of city clusters, including the integrated development of Beijing, Tianjin and Hebei, the Yangtze River Delta and the Pearl River Delta. In addition city clusters will be formed in northeastern China, central China, the middle reaches of the Yangtze River, the Chengdu-Chongqing area and the Guangzhong Plain.

Realizing that China is still weak in research and development as well as innovation, the draft plan stipulates that China will promote a group of national key scientific and technological programmes. The goal is to make breakthroughs in the development of core technologies in fields such as 'next-generation information communications, new energy, new material, aerospace, biology, medicine, and intelligent manufacturing' (Xinhua 2015c: 7).

The draft extends plans for quality, efficiency and innovation to the agricultural sector. It states that the government will push for agricultural modernization that is 'high-efficient, resource-conserving and environmentally-friendly and features safe products' (Xinhua 2015c: 7). Concerning agricultural product quality the draft plan emphasizes the necessity to institute a safety supervision system that covers the whole process from farmland to dining table.

\section{SOE reform}

The need for SOE reform has been widely discussed in China as well as abroad. The comprehensive reform program adopted at the 3rd Plenary Session of the Central Committee in November 2013 advocated substantial SOE reform based on the overall principle of upholding the market as 'the decisive force' (Xinhua 2013). The draft Five-Year Plan only briefly touches on the decisive role of the market in resource allocation and has little to say on SOE reform. It mentions that private enterprises will be encouraged to enter more sectors and that nonstate-owned capital will be introduced into the reform of state-owned enterprises, but at the same time it states that China will 'endeavor to make state-owned enterprises stronger, better, and bigger, so that they can better serve the national strategic goals' (Xinhua 2015c: 9). In short, on the one hand the leadership wishes to introduce more competition in the state-owned sector, on the other hand an attempt will be made to create even stronger and bigger enterprises. This seems to involve 
contradictory policies. Chinese planners argue that in order to be able to compete on the global-level playing field, Chinese companies need to merge with other companies in their sector in order to be large enough to cope with the competition from western multinationals. How this can be implemented without creating even bigger monopolies in the home economy remains a mystery.

In relation to external economic relations the draft plan has a paragraph on RMB convertibility. The Chinese government will strive to achieve this goal and will also promote the RMB to be added to the basket of currencies used to value the SDR, a reserve currency created by the IMF in 1969. If approved RMB will be included in the SDR basket from 1 October 2016 (Orlik and Chen 2015). China will also work to establish more bilateral investment treaties and advance the 'one belt, one road initiative', the construction of the Asian Infrastructure Investment Bank (AIIB) and the New Development Bank of the BRICS countries (Xinhua 2015c: 18). All these initiatives will clearly advance China's influence in the international economic system and has the potential of creating an alternative to the US-dominated Breton Woods system.

It is noteworthy that the draft plan also addresses the Taiwan issue and stipulates that 'we should uphold the "1992 Consensus" and the one-China principle and stick to the belief that two sides of the Taiwan straits belong to one family' (Xinhua 2015c: 18). One week after the Central Committee concluded its session, $\mathrm{Xi}$ Jinping met in Singapore with Taiwan's president, Ma Yingjiu. There is no official indication that the CCP Central Committee discussed the Taiwan issue. Apparently Xi Jinping took this initiative after consulting with very few people in the senior leadership.

\section{Public service}

Section VII is about enhancing the 'wellbeing of the people'. This involves increasing and improving the supply of public service. In order to realize this objective, the intention is to outsource public service to social undertakings (shetuan). In fact it is stipulated that 'if the government can purchase the service, it will not directly offer the service itself' (Xinhua 2015c: 20). Already reforms along these lines have been conducted in Guangdong province and now the government plans to extend the experiment to the whole country. If implemented it will in fact hollow out the government's welfare obligations and open the door to further privatization of public service (health care, elderly care, education) in China. 
In sector VII it is also stipulated that the government will implement a policy of 'one couple with two babies at most'. This indicates an end to the one-child policy and is the greatest change in China's family planning in three and a half decades. The decision aim to create a balanced population development and solve the aging population problem. However the reform is unlikely to make a big change in the trend of population growth. Many couples in the city are not likely to have more than one child and, even if they did, it would take a long time to reverse the trend of declining population. Therefore, in the short- to medium term China will still face serious population challenges, including a steady decline in the work-age population.

\section{Inequality}

In recent years income gaps have widened in China. This has to a certain extent been a deliberate policy on the part of the government. But some business executives have had pay packages amounting to several million RMB. In some cases business leaders have earned salaries several hundred times the average pay of their own employees (Brødsgaard 2015). The development of the private economy has also contributed to rising income inequalities. China now has more billionaires than the US. It is estimated that the total assets of the super-rich have soared to 31 trillion RMB, equal to 10 times the GDP of Norway and 20 times that of the Philippines (China Daily 2015).

The new Five-Year Plan stipulates that 'the income gap should be narrowed, with the proportion of people with middle income increased' (Xinhua 2015c: 4). The overall goal is that 'the average income of urban and rural residents should be double those of 2010'. Poverty alleviation is also part of the programme. The goal is to lift 70 million people above the poverty line by 2020. This is the group of poor people who live below the national poverty line of 2,300 RMB in annual income.

\section{Corruption}

Section VIII of the draft plan is about the need to strengthen the Party's capacity to provide leadership for the realization of the 13th Five-Year Plan. Party leadership and institutional strengthening have been a central issue for the leadership since Xi Jinping took over as Party leader in November 2012. A wide range of Party documents, concerning issues such as selecting and appointing Party leaders (People's Daily 2015), 
establishing Party groups (dangzu) in all government agencies and organizations as well as in private companies and NGOs (Xinhua 2015a), and about training and re-education, have been circulated.

Strengthening the Party's governing capacity involves upholding the principle of clean government. A few days before the plenary session, the Central Committee issued new rules on clean government and sanctions for those officials who violate the Party's code of conduct (Xinhua 2015b). They are the latest regulations circulated in a widespread anticorruption and anti-graft campaign that has been going on since late 2013. During the campaign more than 100 officials at ministerial level and above have been brought down, including two former vice chairmen of the Central Military Commission, generals Xu Caihou and Guo Boxiong as well as former head of China's security apparatus and member of the Politburo Standing Committee, Zhou Yongkang. At lower levels tens of thousands of cadres have been detained and investigated. The campaign shows no sign of stopping and its continuation seems to define the 'new normal' in Chinese politics. In terms of elite politics the campaign has strengthened Xi Jinping and his close ally Wang Qishan, who together with another member of the Politburo Standing Committee Yu Zhengsheng, dominate the top policy-making organs in the Party.

\section{Conclusion}

The building of a so-called 'moderately affluent society in a comprehensive manner by 2020 ' is the first centenary goal set by the CCP. The second centenary goal is to establish a 'modern socialist country' by 2049, when the People's Republic of China marks its centennial. Future Five-Year Plans will be prepared under the guidance of this goal.

The new Five-Year Plan, to be implemented from 1 January 2016, will be the first to have been formulated according to China's 'new normal'. The economic growth rate is expected to slow down around 6.5 per cent. Although this is a significantly reduced growth rate compared to the hyper growth of the past 35 years, it is high enough to double the Chinese GDP from 2010 to 2020. China's GDP has already surpassed the US' in terms of purchasing power parities. By 2020 the size of China's economy will most likely have reached that of the US in nominal terms.

However, proposals for the new Five-Year Plan indicate that the shift to a more balanced economic development process already embedded in the current 12th Five-Year Plan will deepen. This involves focus on green and innovation-driven development, upgrading of the industrial 
structure and output, increasing the contribution of consumption to economic growth and reducing the role of investment, raising people's living standards and quality of life, eliminating remnants of rural poverty, advancing environmental protection and modernizing the national governance system. In order to ensure that Party and state officials follow the line and do not engage in corrupt and wasteful practices, the current anti-corruption campaign will continue.

Chinese Five-Year Plans read like a catalogue of ideas and abstract work assignments. Analysis and reflection are absent and western scholars often wonder whether they serve any practical purpose. As they now contain fewer concrete quantitative goals than in the past, they do not serve as a concrete to-do list determining the actual mobilization and allocation of material resources. However, this does not mean that they are insignificant. All China's 31 provinces most work out similar plans, translating national guidelines into local realities. This will involve major planning work for provincial bureaucracies. Moreover, although central planning in a quantitative sense is less rigorous than in the past, Five-Year Plans are still important as they serve as guidelines to the economic thinking of the CCP and state leaders. They must therefore be carefully studied.

Kjeld Erik Brødsgaard is Professor in the Department of International Economics and Management and Director of the China Policy Programme, Copenhagen Business School. Email: keb.int@cbs.dk

\section{REFERENCES}

Brødsgaard, Kjeld Erik 2011. 'A Note on China's 12the Five-Year Plan.' The Copenhagen Journal of Asian Studies 29(2): 143-153.

Brødsgaard, Kjeld Erik 2015. 'Gaige shiqi guoqi gaoguan de shehui yu zhengzhi liudong: Zhongguo chaoji jingli ren de jueqi' (Social and Political Mobility of SOE Leaders in the Era of Reform: The Rise of Chinese Supermanagers, in Zheng Yongnian (ed.) Gaige: Kunjing yu chulu (Reform: Predicament and Future). Beijing: Dongfang chubanshe: 11-126.

Brødsgaard, Kjeld Erik and Koen Rutten 2015. From Accelerated Accumulation to the Socialist Market Economy: Chinese Economic Discourse and Development From 1953 to Present. Copenhagen (unpublished manuscript).

China Daily, April 6, 2015. Available at http://usa.chinadaily.com.cn/epaper/201504/06/content_20009445.htm (accessed 26 July 2015).

National Bureau of Statics of China 2015. '2014 nian guomin jingji he shehui fazhan tongji gongbao' (Statistical Communiqué of China on the 2014 National Economic and Social Development). Beijing: Zhongguo tongji chubanshe.

Orlik, Tom and Fielding Chen 2015 'China's Yuan - Between Stability and Decline.' Bloomberg Brief/China Brief, November 30. 
People's Daily 2015. 'Dangzheng lingdao ganbu xuanba renyong gongzuo tiaoli.' (Working Regulations Concerning the Selection and Appointment of Leading Cadres), July 16. Available online at: http://renshi.people.com.cn/n/2014/0116/c13961724132478.html (accessed 24 July 2015).

Wübbeke, Jost and Björn Conrad 2015. 'China's Climate Promises Under Economic Pressure: Scenarios and Implications.' MERICS China Policy Brief, November.

Xinhua 2013. 'Zhonggong zhongyang guanyu quanmian shenhua gaige ruogan zhongda wenti de jueding.' (CPC Central Committee Decision On Several Major Issues Of Deepening Reform). Available online at: http:/ / news.xinhuanet.com/politics/201311/15/c_118164235.htm (accessed 10 November 2014).

Xinhua 2015a. 'Zhongguo gongchandang dangzu gongzuo tiaoli (shixing).' (The Chinese Communist Party's Working Regulations on Party Groups (trial use)), 16 June 2015. Available online at: http://www.gov.cn/zhengce/2015-06/16/content_2880383. htm (accessed 24 July 2015).

Xinhua 2015b. 'Zhongguo gongchandang jilu chufen tiaoli,' (Regulations of the Chinese Communist Party on DisciplinaryMeasures), 21 October 2015. Available online at http://news.xinhuanet.com/legal/2015-10/21/c_1116897567.htm (accessed 1 December 2015).

Xinhua 2015c. 'Zhonggong zhongyang guanyu zhiding guomin jinji he shehui fazhan di sange wunian guihua de jianyi.' (Proposals of the Central Committee of the Communist Party of China on the 13th Five-Year Plan for National Economic and Social Development), adopted by the Fifth Plenary Session of the 18th Central Committee of the CCP, 29 October 2015. Available from: http://news.xinhuanet. com/fortune/2015-11/03/c_1117027676.htm (accessed 2 December 2015).

Yin, Pumin 2015. 'Mapping Out Success.' Beijing Review 58(45): 12-17. 